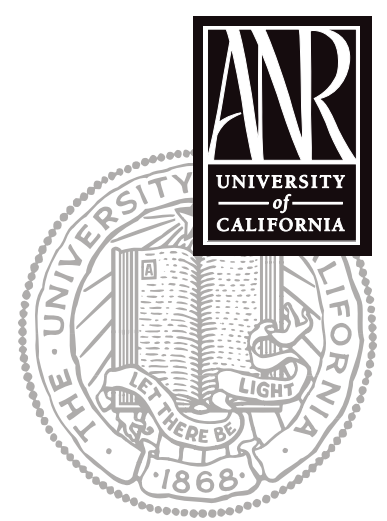

UNIVERSITY OF CALIFORNIA

Division of Agriculture and Natural Resources http://anrcatalog.ucdavis.edu

\title{
Methods to Maintain Genetic Purity of Seed Stocks
}

KENT J. BRADFORD, Professor, Department of Plant Sciences, University of California, Davis

Production and distribution of high-quality seeds is fundamental to modern agricultural systems. The majority of annual crops are established each season from seeds, and seed quality can have a major impact on potential crop yield. Seeds carry the genetic traits incorporated by years of breeding and selection to create varieties that are adapted to specific production environments and will produce high yields and product quality. The genetic purity of seeds (i.e., the percentage of contamination by seeds or genetic material of other varieties or species), their physiological quality (or vigor), and the presence of weed seeds, seedborne diseases, or other materials (dirt or plant residues) contribute to overall seed quality.

\section{Are standards established for seed genetic purity?}

The genetic purity of any commercial agricultural product propagated by seed begins with the purity of the seed planted. In general, the genetic purity of the seed planted must equal or exceed the final product purity standard required, as purity generally decreases with each subsequent generation of propagation. On the other hand, it is virtually impossible to assure that no off-type plants or pollen are present in the seed production field and that all handling and conveyance equipment and storage facilities are completely free of contamination, so commercial planting seed is seldom $100 \%$ pure. In practice, seed genetic purity standards have been established by state seed laws and by seed certification agencies to ensure that the purchaser receives seed that is within certain purity tolerances. These tolerances are established based on the biology of the species (i.e., self- or cross-pollinated), the type of variety (i.e., openpollinated or hybrid), and market-driven standards for final product quality. Earlier generations of seed (e.g., foundation or registered seed) have stricter standards in order to be able to meet the certified seed purity criteria. According to the Association of Official Seed Certifying Agencies (AOSCA 2003), the maximum limits for seed of other varieties or off-types in foundation seed lots range from 0 to $0.2 \%$ among different species, while the limits for certified seed range from 0.1 to $2 \%$ by weight. In practical terms, the maximum number of seeds of other varieties of the same crop permitted in 1 pound of certified seed is 1 for cotton and wheat, 2 for watermelons, 4 for rice, and 6 for sunflowers (CCIA 2005).

\section{What is seed certification?}

Seed certification systems were established during the first half of the twentieth century to maintain the genetic identity and purity of publicly developed varieties that were released primarily from state agricultural experiment stations. Seed certification schemes are based on a pedigree system in which seeds for sale to a grower (i.e., certified seeds) are a limited number of generations from a verified seed stock of the specified variety. Generally, breeder's seed produced under the strictest standards and under the supervision of the breeder is used to produce foundation seed, which is used to produce registered seed, which is used to produce certified seed that is sold for commercial planting. The number of generations employed depends on the seed increase that can occur per generation and on the quantities of seed required to meet market demands. 
In addition to documenting the pedigree of the source seed, seed certification programs also have requirements concerning crop rotations, previous crops and weeds in the intended field, and isolation of the field from other varieties of the same genus or species. Inspectors from seed certifying agencies walk through each field, noting the occurrences of any off-type plants, other crop plants, weeds, or diseases and determining whether these are within the tolerances for the certification level of the seed crop. A field failing to meet the standards is rejected for certification. In addition, after harvesting and cleaning (conditioning), the seed is tested for germination capacity and analyzed for the presence of seeds of other varieties or other crops, weed seeds, and inert matter to assure high overall seed quality before official tags are issued that identify each bag as being certified seed.

In the United States, seed certification is used primarily for field crops (cereals, soybeans, sunflowers, alfalfa, etc.) and for both publicly and privately developed varieties. Cooperative agreements with seed certification schemes in other countries (e.g., the Organization for Economic Co-Operation and Development [OECD] scheme in Europe) facilitate international trade in seed by assuring mutually recognized minimum quality standards. Seed certification is seldom utilized in the vegetable and horticultural industries, although seed companies employ similar pedigree, isolation, and purity standards in their internal production practices to meet market standards and customer expectations.

\section{What are the consequences of genetic engineering for seed genetic purity?}

In general, seed certification programs in field crops and market competition in highervalue crops have been effective in providing high-quality seeds for agriculture. The introduction of genetically engineered (GE) varieties (those developed using recombinant DNA techniques in addition to sexual crossing and selection) has created additional issues for seed genetic purity, particularly for producers seeking to meet organic marketing standards or who are engaged in international trade. The U.S. National Organic Program (NOP) does not allow the use of seed developed using recombinant DNA techniques to produce crops that will be certified as organic (NOP 2002). It also requires the use of seeds that have been produced using organic methods when such seeds are commercially available. Although current regulations do not specify an acceptable threshold level for the adventitious (unintended) presence of GE materials in an organic product (i.e., there is an implied zero tolerance), there is also no requirement to test for such adventitious presence. Therefore, a grower would not automatically lose organic certification if such inadvertent contamination occurred. Nonetheless, it is clearly the expectation of consumers purchasing organic foods that those foods do not contain materials developed using genetic engineering. In addition, GE varieties are individually regulated by national agencies, so approval generally is required from the importing country before those varieties can be legally traded. The presence of even a small amount of an unapproved GE variety, if detected, can block an entire shipment. Thus, achieving and maintaining high seed genetic purity has become even more important following the introduction of GE varieties.

\section{How can the genetic purity of seed stocks be maintained?}

The principles for producing seed crops that are free of GE materials are the same as those for seed certification. The main sources of contamination of a seed crop are the prior crop grown in a field, transfer of pollen from a nearby field, and mixtures during harvesting and handling. Obviously, a seed crop intended to be free from GE materials should not be grown in a field that has previously grown a GE crop of the same species within the past 3 to 5 years to ensure that volunteer plants will not be present. To prevent pollen transfer from a GE crop to a conventional or organic seed crop, fields must 
be isolated either spatially or temporally from potentially contaminating pollen sources. The isolation required depends on flower characteristics, sexual compatibility with neighboring crops, pollen quantity and viability, and mode of pollen dissemination (Sundstrom et al. 2002). Self-pollinating crops such as rice or wheat require relatively small isolation distances of 0 to 30 feet $(9 \mathrm{~m})$ designed primarily to prevent mechanical mixtures during harvesting. Cross-pollinating crops, on the other hand, require as much as 1 mile $(1.6 \mathrm{~km})$ or more of isolation from plants of the same species to prevent outcrossing, depending upon the flower structure, the mode of pollen transfer, the duration of pollen viability, and the type of seed being produced (e.g., foundation versus certified or hybrid versus open-pollinated). Seed certification standards serve as a guide to minimum isolation distances for specific crops (CCIA 2005). These guidelines have been found in practice to be sufficient to meet seed certification standards, but pollen movement can be affected by the environment and insect pollinator activity. Recommended isolation distances may need to be increased depending upon the economic impact of contamination. For example, hybrid seed production or production of seeds in which contamination would be readily apparent (e.g., contamination of seeds for white onions with seeds of red onions) often requires greater isolation to achieve purity standards expected in the marketplace. Similarly, longer isolation distances may be required to reduce the likelihood that pollen from outside the field will introduce GE traits into a conventional or organic seed field. Isolation can also be achieved by planting crops at different times so that their flowering periods do not overlap. Border rows around the field that are not harvested with the seed crop can also be employed to intercept stray pollen and reduce contamination of the remainder of the field.

In the seed industry, it is the responsibility of the seed producer to take measures to ensure the genetic purity of the seed crop. This often requires cooperation among different companies and growers producing seed of the same species in the same area and coordination of planting locations and dates. Online mapping tools are available to seed producers in California to assist in coordinating plantings to achieve the isolation required to meet certification or market purity standards (see the CCIA Web site, http://ccia.ucdavis.edu/crop/MapMainPage.htm).

Contamination can also occur during harvesting, conditioning, and handling of the seed. To meet the highest standards, all equipment used in production, including seeding, field maintenance, and harvesting, should be cleaned and inspected before and after each use. All dryers, millers, storage facilities, and processing equipment must be cleaned and inspected between each product lot to assure that segregation is maintained and no physical contamination occurs. Certification agencies have established standard operating procedures for facilities handling seeds and identity-preserved products (AOSCA 2003).

All of the techniques described above are routinely employed in seed production to produce seed lots that have high genetic purity. Achieving even greater purity of the final product generally entails higher costs. A recent study found that relative to standard corn seed production practices, the costs to achieve higher levels of genetic purity (to a $0.3 \%$ GE contaminant threshold) would increase by about $35 \%$ (Kalaitzandonakes and Magnier 2004). Thus, while very high levels of seed purity can be attained, it may be costly to do so. Seed genetic purity thresholds therefore generally reflect a balance between the quality requirements of the market and the costs required to achieve a given purity standard.

\section{PERSPECTIVE}

The genetic purity of seed stocks is important to ensure that growers, processors, and consumers receive the crop varieties and products that they expect. Seed certification programs and seed production companies are experienced in the procedures that are 
required to achieve various levels of seed purity for different species, markets, and uses. The introduction of GE crops has drawn attention to seed purity due to marketing and export restrictions that may require low levels of adventitious presence of GE seeds in conventional seed lots. While $100 \%$ purity (zero tolerance for any undesired components) is very difficult to attain for any seed commodity, standard procedures involving isolation distances, border rows, timing of flowering, cleaning of equipment, and postharvest handling can provide seed to meet diverse market requirements.

\section{BIBLIOGRAPHY}

AOSCA (Association of Official Seed Certifying Agencies). 2003. Operational procedures, crop standards and service programs publication. AOSCA Web site, http://www.aosca.org/2004\%20Yellow\%20Book,\%20pdf.pdf.

CCIA (California Crop Improvement Association). 2005. Certification standards. CCIA Web site, http://ccia.ucdavis.edu.

Kalaitzandonakes, N., and A. Magnier. 2004. Biotech labeling standards and compliance costs in seed production. Choices 19(2):1-9.

NOP (National Organic Program). 2002. National Organic Program final rule. NOP/ AMS/USDA Web site, http://www.ams.usda.gov/nop/.

OECD (Organization for Economic Co-Operation and Development). 2005. OECD seed schemes 2005: Rules and directions. OECD Web site, http://www.oecd.org/agr/seed.

Sundstrom, F. J., J. Williams, A. Van Deynze, and K. J. Bradford. 2002. Identity preservation of agricultural commodities. University of California Division of Agriculture and Natural Resources Publication 8077. ANR Communication Services Web site, http://anrcatalog.ucdavis.edu/pdf/8077.pdf.

To order or obtain printed ANR publications and other products, visit the ANR Communication Services online catalog at http://anrcatalog.ucdavis.edu. You can also place orders by mail, phone, or FAX, or request a printed catalog of our products from:

University of California

Agriculture and Natural Resources

Communication Services

6701 San Pablo Avenue, 2nd Floor

Oakland, California 94608-1239

Telephone: (800) 994-8849 or (510) 642-2431

FAX: (510) 643-5470

E-mail inquiries: danrcs@ucdavis.edu

An electronic version of this publication is available on the ANR Communication Services Web site at http://anrcatalog.ucdavis.edu.

Publication 8189

(C) 2006 by the Regents of the University of California, Division of Agriculture and Natural Resources. All rights reserved.

The University of California prohibits discrimination or harassment of any person on the basis of race, color, national origin, religion, sex, gender identity, pregnancy (including childbirth, and medical conditions related to pregnancy or childbirth), physical or mental disability, medical condition (cancer-related or genetic characteristics), ancestry, marital status, age, sexual orientation, citizenship, or status as a covered veteran (covered veterans are special disabled veterans, recently separated veterans, Vietnam era veterans, or any other veterans who served on active duty during a war or in a campaign or expedition for which a campaign badge has been authorized) in any of its programs or activities. University policy is intended to be consistent with the provisions of applicable State and Federal laws. 
$\bigcup_{P \in E R}$

REVIEWED
Inquiries regarding the University's nondiscrimination policies may be directed to the Affirmative Action/Staff Personnel Services Director, University of California, Agriculture and Natural Resources, 300 Lakeside Drive, 6th Floor, Oakland, CA 94612-3550 (510) 987-0096. For a free catalog of other publications, call (800) 994-8849. For help downloading this publication, call (530) 754-5112.

To simplify information, trade names of products have been used. No endorsement of named or illustrated products is intended, nor is criticism implied of similar products that are not mentioned or illustrated.

This publication has been anonymously peer reviewed for technical accuracy by University of California scientists and other qualified professionals. This review process was managed by the ANR Associate Editor for Agronomy and Range Sciences.

pr-3/06-SB/CR

ISBN 978-1-60107-402-7 